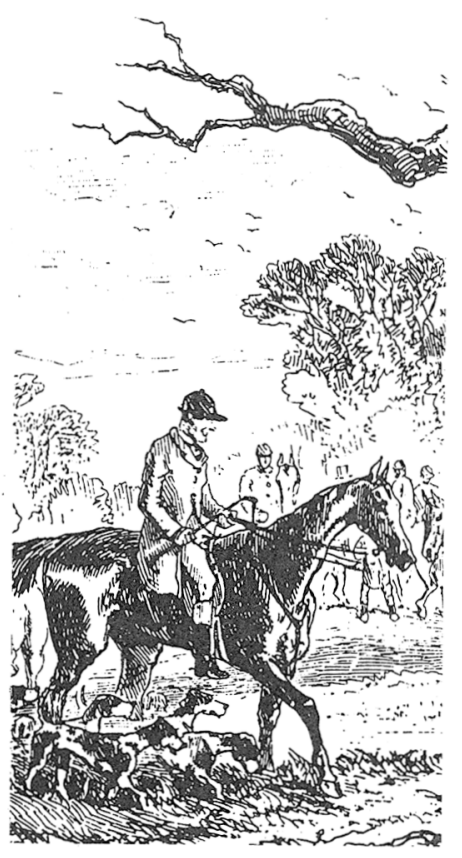

TROLLOPE AND

\section{COMIC PLEASURE}

\section{CHRISTOPHER HERBERT}

"Herbert's work is startlingly original, asserting with real authority the crucial place of pleasure in comedy, the astonishing complexity of the mode, and the intricacy and vividness of Trollope's play within the form."-James R. Kincaid, University of Colorado, Boulder

Cloth \$24.00 258 pages

1 line drawing

\section{DEATH IS THE}

\section{MOTHER OF BEAUTY}

Mind, Metaphor, Criticism

MARK TURNER

With a Foreword by George Lakoff

" [This] is a book of linguistic and critical theory deeply immersed in particular metaphors and their effects. To me it offers more sheer pleasure than any other book on metaphor, and the fun pays off with rich new insights."-Wayne C. Booth, University of Chicago

"A book of importance both to literary scholars and to scientists of the mind-linguists, psychologists, anthropologists, and researchers in artificial intelligence."-George Lakoff, Universtiy of California, Berkeley

Cloth \$16.95 224 pages

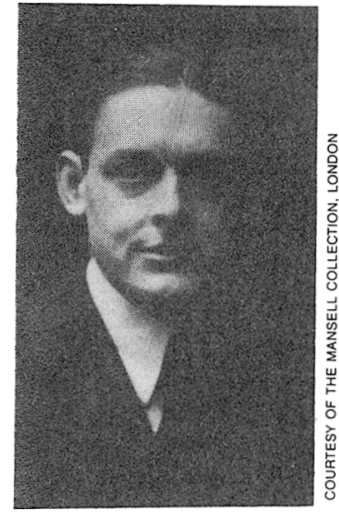

\section{HE DO THE POLICE IN DIFFERENT VOICES}

The Waste Land

and Its Protagonist

CALVIN BEDIENT

"This boldly original close reading of Eliot's 1922 masterpiece is the most complete, adventurous, and stimulating study of The Waste Land I have read. It combines daring with care to avoid the distorting cliches of Eliot criticism."-Lyndall Gordon, Oxford University

Paper \$12.95 240 pages

Library cloth edition $\$ 30.00$

\section{VLADIMIR'S CARROT \\ Modern Drama and the Modern Imagination JOHN PETER}

Is Waiting for Godot the single most important event in the theater since Aeschylus? Or is it the fulfillment of forces at work long before Beckett wrote it? Peter pursues this question through drama, music, art, and philosophy to reveal the sources and features of a distinctly modern imagination.

\section{Cloth $\$ 24.95376$ pages}

\section{THE SPY STORY}

JOHN G. CAWELTI and

BRUCE A. ROSENBERG

The authors explore the social, political, and artistic sources of the spy story's wide appeal. They show how, in a time of bewildering political and corporate organization, the secret agent hero has come to express the feelings of divided and ambiguous loyalties with which many individuals face the modern world.

Cloth $\$ 22.50272$ pages

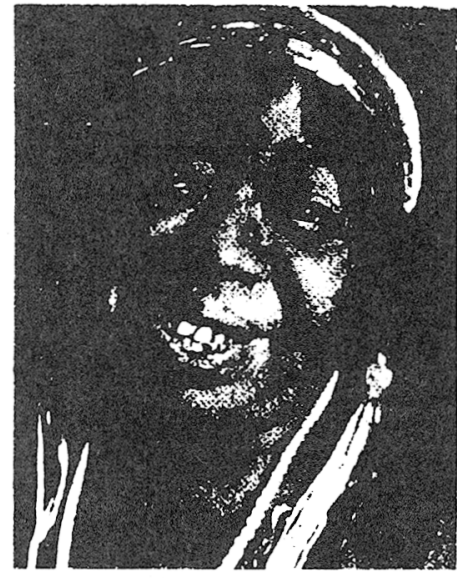

MODERNISM AND THE HARLEM RENAISSANCE HOUSTON A. BAKER, JR.

"An extended essay, a mixture of analysis and personal testimony, seeking to identify a distinctively Black 'sound' underlying and informing Black creativity... .The book is powerful and generative, controversial, provocative, and original."--Hayden White, University of California, Santa Cruz

“A truly brilliant work.,'-Henry Louis Gates, Jr., Cornell University Cloth \$19.95 144 pages 15 halftones

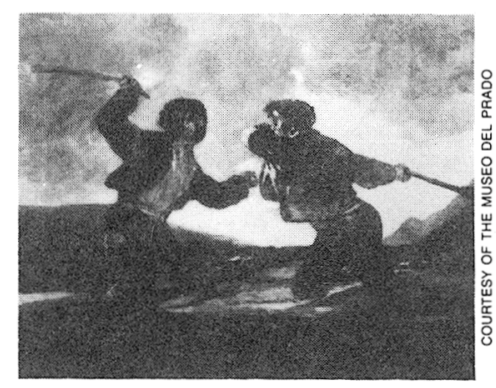

TEXTUAL CONFRONTATIONS

Comparative Readings in Latin American Literature ALFRED J. MAC ADAM

"[Mac Adam] reveals that while Latin American literature is rooted in Western culture, it has used its originality and renovating energy to reinvigorate the Western tradition. The book combines analytic rigor with an imaginative, useful vision of literary relationships.'-Mario Vargas Llosa

Cloth $\$ 19.95216$ pages 


\section{Criticism \& Interpretation from Cornell}

\section{Dialectical Images} Walter Benjamin's Theory of Literary Criticism

By MICHAEL $W$. JENNINGS. Combining readings of Benjamin's texts with close examination of the development of his theory of the work of art, Jennings reveals how Benjamin formulated a critical practice that was also an inquiry into epistemology and the philosophy of history.

\section{From Song to Book}

The Poetics of Writing in Old French Lyric and Lyrical Narrative Poetry By SYLVIA HUOT. The medieval illuminated manuscript, Huot asserts, has a theatrical, performative quality. In this book, she argues that the tension between implied oral performance and real visual artifact is a fundamental aspect of thirteenth- and fourteenth-century poetics. 31 black-and-white illustrations.

$\$ 38.50$

\section{The Sense of the "Song of Roland"}

By ROBERT FRANCIS COOK. This book offers an interpretation of the Song of Roland, one of the bestknown texts in all of heroic literature. It also treats the poem's place in the eleventh (or early twelfth) century, its importance to the society that produced it, and the ways in which it is read today. $\$ 34.50$
The Romantic Foundations of the American Renaissance By LEON CHAI. "An ambitious work of synthesis which establishes surprising yet convincing connections between American and European works, Leon Chai's book gives us a new and fascinating American Renaissance which we have not seen in Matthiessen or Bercovitch."-Jonathan Culier, Cornell University $\$ 29.95$

\section{Masks of Tradition} Women and the Politics of Writing in Twentieth-Century France By MARTHA NOEL EVANS. Evans presents close readings of texts in which the central narrative strand concerns a woman's struggle to make a place for herself as a writer: The Vagabond by Colette, She Came to Stay by Simone de Beauvoir, La Batarde by Violette Le Duc, The Ravishing of Lol V. Stein by Marguerite Duras, Portrait of Dora by Hélène Cixous, and The Lesbian Body by Monique Wittig. $\$ 24.95$

\section{Legislators and Interpreters On Modernity, Post-Modernity, and Intellectuals}

By ZYGMUNT BAUMAN. After examining the historical conditions in which the modern world view and its characteristic intellectual strategy were formed, Bauman discusses how this strategy was challenged, and partially supplanted, by an alternative "post-modern" view. $\$ 39.95$

\section{The Challenge of Bewilderment Understanding and Representation in} James, Conrad, and Ford By PAUL B. ARMSTRONG. "A very valuable book-an unusually lucid, careful, and helpful work that both advances our understanding of three novelists and illuminates the interpretive practices on which all narrative fiction depends and in which all readers of fiction engage." -Ruth Bernard Yeazell, University of California, Los Angeles. \$29.95

\section{Rousseau's}

\section{Exemplary Life}

The "Confessions" as

Political Philosophy

By CHRISTOPHER KELLY. Beginning with an examination of Rousseau's fascination with the genre of autobiography, this stimulating new approach to one of the central books of the Western tradition breaks down the artificial distinction traditionally made between the Confessions and Rousseau's overtly philosophical works. $\$ 29.95$

Momentary Monsters Lucan and His Heroes

By W. R. JOHNSON. A distinguished classicist offers a challenging reading of the Roman poet Lucan (A.D. 39-65) which casts new light on the Pharsalia, his epic poem and only surviving work. "Entertaining, bristling with good humor and insight, and properly skeptical about the vagaries of the current literary establishment, both classical and modern."-Charles Witke, University of Michigan. \$17.95 